\title{
Bonding of DATB - Progress Report
}

\author{
P. B. Archibald
}

\section{DISCLAIMER}

This report was prepared as an account of work sponsored by an agency of the United States Government. Neither the United States Government nor any agency thereof, nor any of their employees, makes any warranty, express or implied, or assumes any legal liability or responsibility for the accuracy, completeness, or usefulness of any information, apparatus, product, or process disclosed, or represents that its use would not infringe privately owned rights. Reference herein to any specific commercial product, process, or service by trade name, trademark, manufacturer, or otherwise does not necessarily constitute or imply its endorsement, recommendation, or favoring by the United States Government or any agency thereof. The views and opinions of authors expressed herein do not necessarily state or reflect those of the United States Government or any agency thereof.

ration

JAN 291997

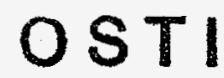

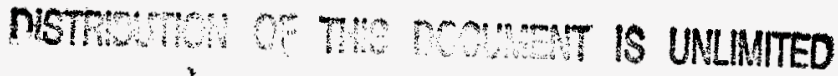

August 2, 1958

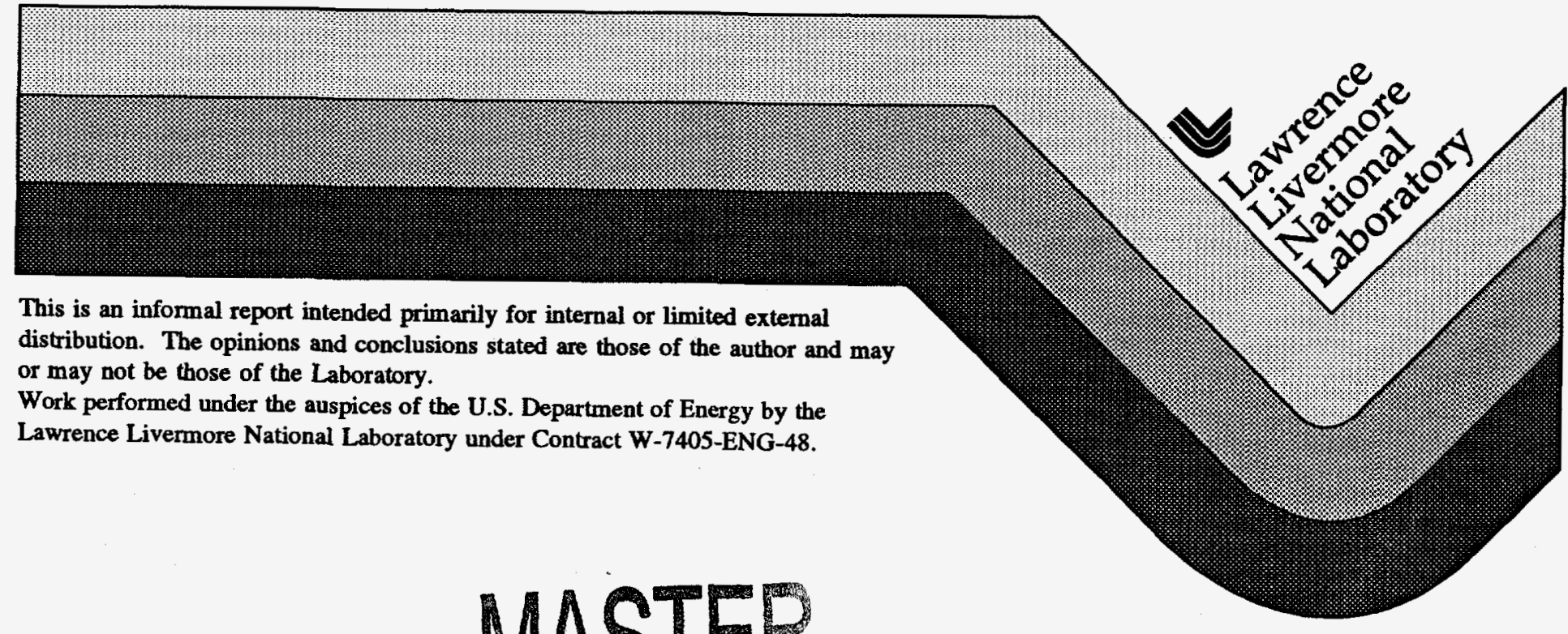




\section{DISCLAMMER}

Portions of this document may be illegible in electronic image products. Images are produced from the best available original document. 


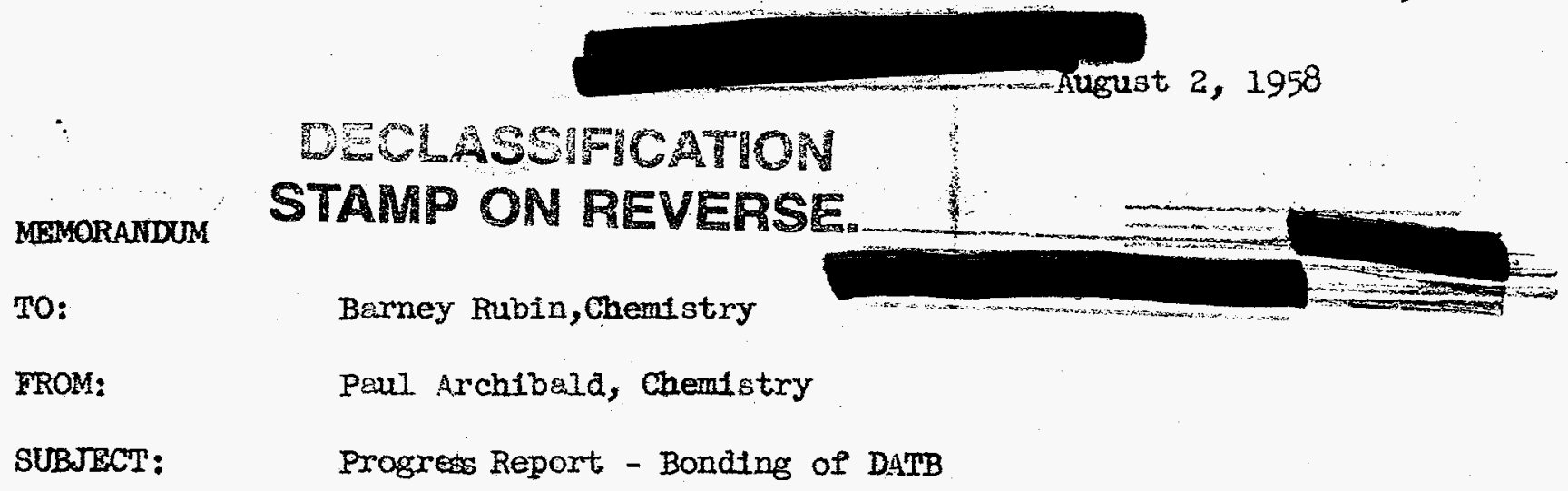

Sunmary: A serles of DATB (diaminotrinttrobenzine) pressings were made in an effort to find the most suitable binder. The requirements for this binder were as follows:

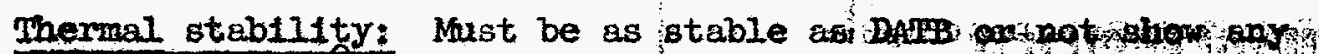
reaction with DATB at $200^{\circ} \mathrm{C}$.

Density: Must press to 95\% theoretigd 120 tgher $8101-5659$ Compressive Strength: stronger $1 \hat{f}$ possible.

Moldablitty Must b Nust be strong engugh to machitic and

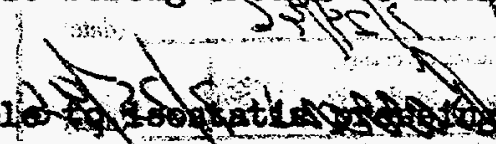

After investigationg various materials such as epoxys, a high temperature silibcon phenolic and exon It was found that DATB could be not pressed at $110 \mathrm{C}$ and $20,000 \mathrm{ps} 1$ to an acceptable density and strength. While a plastic binder is not needed for reasons of strength or desensitization it may however be needed as a plasticizer to resist thermal shock. This can only be determined by the production of larger specimens at Site 300 . See Table I for summarized data.

Epoxy Binders: Epon 828 with $30 \%$ Versamide 125, when wet ball milled into the DATB in amounts of 3 or $5 \%$ gave a materlal which was thermally stable and with a good density and compressive strength when pressed in the hydraulic press. However when the conditions of the isostatic press were mocked up it became apparent that due to the thermosetting nature of this binder, it would be only with some difficulty that this binder could be used.

Exon 461: This material can be ball milled dry into the DATB and gives a high strength, high density material, which could be adapted to the isostatic press. However it contains $40 \%$ chlorine snd might not be acceptable in all coses where it is desired to employ DATE.

Hot Pressing of DAMB: Initicily it was assumed that the particle size distribution was a mitor problem in pressing DATB. Thts was indicated by the low buik density, the loit density of cold pressed specimens, and the increase
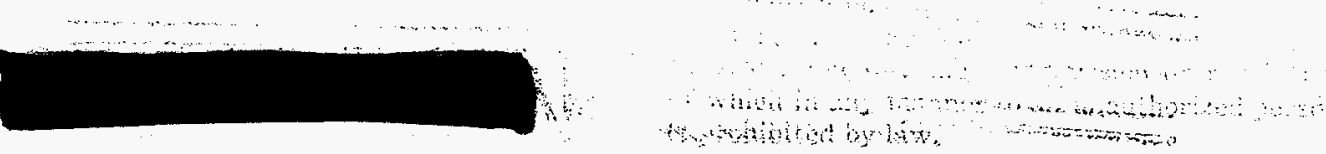


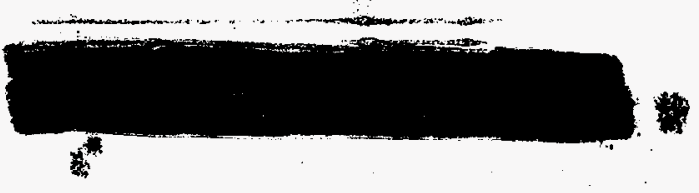

101

SUBJECT: Progress Report - Bonding of DATB

In density with increasing length of time of ball miling in the epoxy system.

After successfully preseing ball milled DATB at $110^{\circ} \mathrm{C}$ it was found that normal DATB (fine powder) could also be hot pressed at this temperature and at 20,000 psi.

Bulk Density of DATB Powder:

Fine powder as recelved

" $"$ "

Coarse powder ground \& hours

Cold pressed and reground
$.47 \mathrm{gms} / \mathrm{cc}$

$.61 \mathrm{gms} / \mathrm{cc}$ (when shaken down)

$.62 \mathrm{gms} / \mathrm{ce}$

$.84 \mathrm{gris} / \mathrm{cc}$ (when shaken dowm)

It should be noted that bulk denstty might vary from batch to batch.

Attached: Table I.

cc: Gus Doraugh.

PBA/ J8 


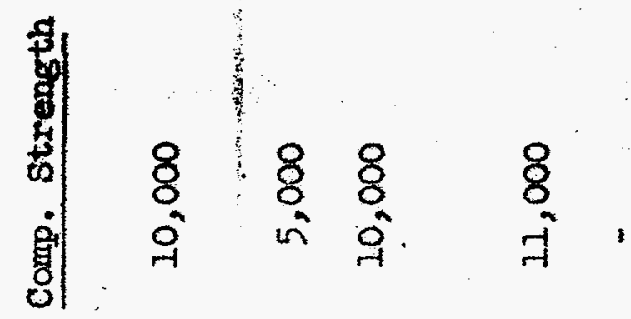

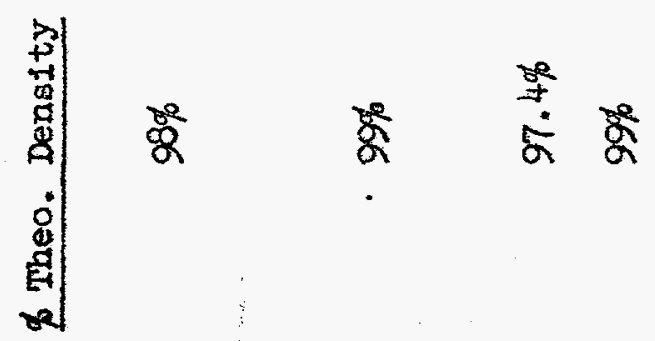

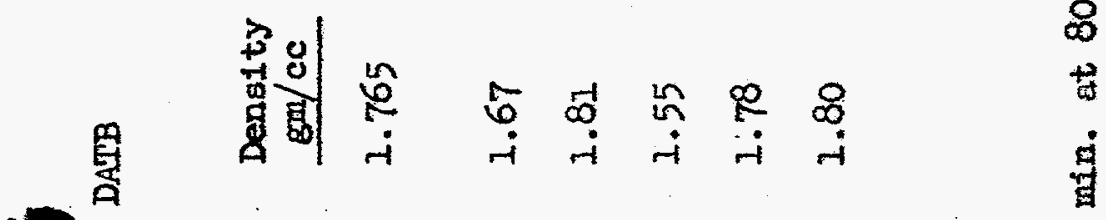

0
7
4
0
0
0
0
0
0
0
4
7
7
7
0
0
9
0
0
0
8

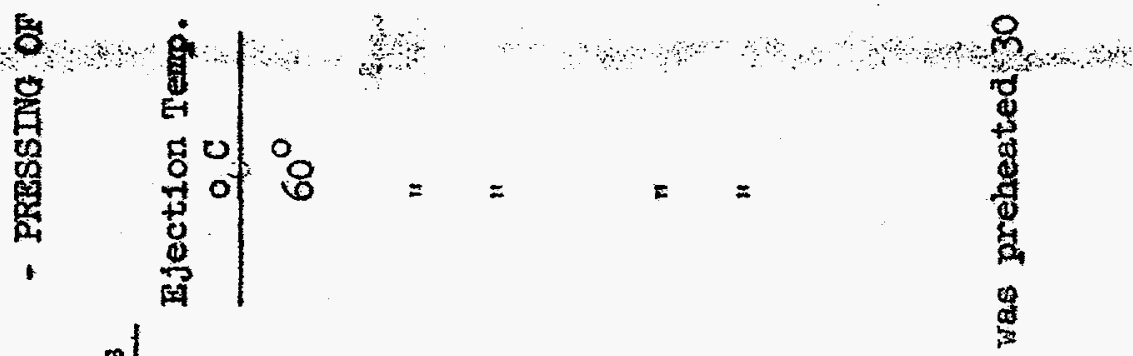

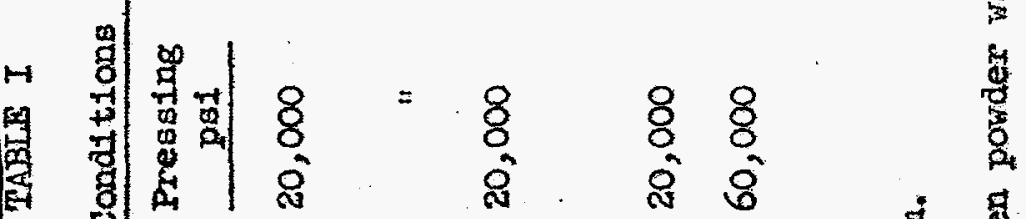

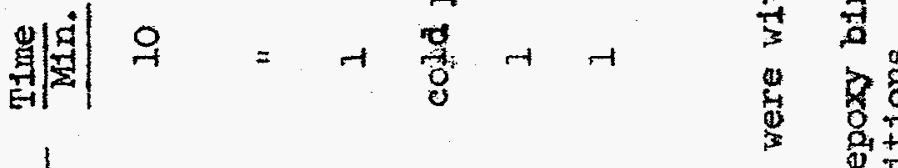

sel $m=n$

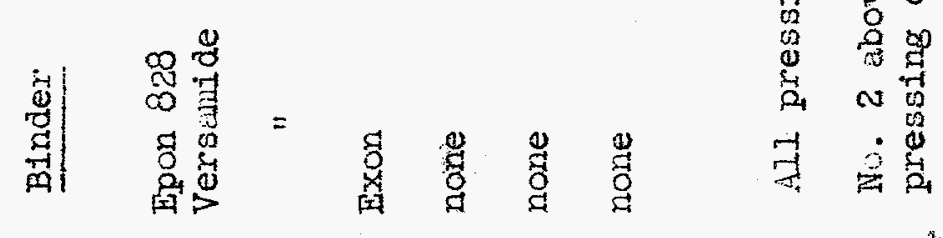

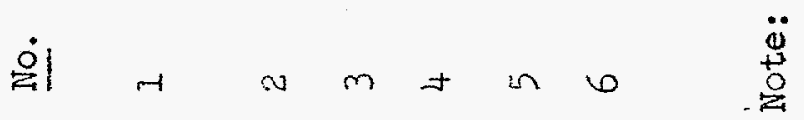

